\title{
Human Intestinal Parasites in the Past: New Findings and a Review
}

\author{
Marcelo Luiz Carvalho Gonçalves, Adauto Araújo/ ${ }^{+}$, Luiz Fernando Ferreira
}

Escola Nacional de Saúde Pública-Fiocruz, Rua Leopoldo Bulhões 1480, 21041-210, Rio de Janeiro, RJ, Brasil

\begin{abstract}
Almost all known human specific parasites have been found in ancient feces. A review of the paleoparasitological helminth and intestinal protozoa findings available in the literature is presented. We also report the new paleoparasitologic findings from the examination performed in samples collected in New and Old World archaeological sites. New finds of ancylostomid, Ascaris lumbricoides, Trichuris trichiura, Enterobius vermicularis, Trichostrongylus spp., Diphyllobothrium latum, Hymenolepis nana and Acantocephalan eggs are reported. According to the findings, it is probable that $\mathrm{A}$. lumbricoides was originally a human parasite. Human ancylostomids, A. lumbricoides and $\mathrm{T}$. trichiura, found in the New World in pre-Columbian times, have not been introduced into the Americas by land via Beringia. These parasites could not supported the cold climate of the region. Nomadic prehistoric humans that have crossed the Bering Land Bridge from Asia to the Americas in the last glaciation, probably during generations, would have lost these parasites, which life cycles need warm temperatures in the soil to be transmitted from host to host. Alternative routes are discussed for human parasite introduction into the Americas.
\end{abstract}

Key words: paleoparasitology - ancient diseases - helminths - protozoa - coprolites - mummies

Parasites are organisms that found their ecological niche living in organisms of distint species, called hosts. Paleoparasitology is the study of parasites in archaeological material. Paleoparasitologic findings can provide valuable information related to the antiquity of humanparasite relationship, parasite dispersion and human migrations in the past (Wilke \& Hall 1975, Horne 1985, Araújo et al. 1988, Araújo \& Ferreira 1997, 2000, Reinhard 1990, 1992).

Fecal remains usually are found in archaeological strata during archaeological excavations, in sediment from ancient latrines and cesspits or directly collected from mummies. Specimens are preserved by dry environment or by high concentration of soluble salts (Fry 1985). When feces are desiccated or mineralized, they are called coprolites (Heizer \& Napton 1969).

Rehydration of desiccated coprolites is necessary to proceed to paleoparasitological analysis. Water, sodium hydroxide and EDTA solutions have been used to rehydrate specimens, but it was observed that they caused egg distortion and disintegration (Fry 1985). Only after the use of trisodium phosphate solution by Callen and Cameron (1960), rehydration techniques could obtain reliable results. They adapted the technique employed by Van Cleave and Ross (1947) and by Benninghoff (1947) to rehydrate dried zoological and herbarium specimens respectively. Since 1960, rehydration in aqueous $0.5 \%$ trisodium phosphate solution has been the standard technique. To disaggregated mineralized coprolites, 5-10\% chlorydric acid solution is used (Jones 1983). Parasite re-

Supported by CNPq, Capes/Cofecub, Papes/Fiocruz. +Corresponding author. Fax: +55-21-2598.2610. E-mail: adauto@ensp.fiocruz.br

Received 26 August 2002

Accepted 25 November 2002 mains, mainly eggs and larvae, can be identified quite easily in ancient fecal material after rehydration.

This paper summarizes the available literature about intestinal parasite findings in archaeological material. We discuss some biological aspects of the parasites found and we speculate about human dispersion in the past. We also performed the examination of ancient feces belonging to the collection of the Laboratory of Paleoparasitology of the Escola Nacional de Saúde Pública-Fundação Oswaldo Cruz (Fiocruz), Rio de Janeiro, Brazil.

\section{MATERIALS AND METHODS}

Specimens - A total of 894 samples of probable human coprolites and organic material from latrines and cesspits, belonging to the collection of our laboratory, were examined. Their origin are listed in Table I. The samples were dated either by ${ }^{14} \mathrm{C}$ method or by cultural context.

Examination techniques - The specimens were rehydrated by immersion in a $0.5 \%$ aqueous solution of trisodium phosphate for $72 \mathrm{~h}$ (Callen \& Cameron 1960). The rehydrated sample solutions were mixed approximately 10:1 in acetic formalin solution to avoid fungal and bacterial growth. The material was allowed to sediment following the technique proposed by Lutz (1919). A portion of each sediment was used for microscopic examination. The material was placed on a slide and covered with a coverslip and examined for the presence of parasites. Twenty slides for each sample were examined at magnification of X100 and X400. All wet preparations were examined by at least two of the authors. All eggs and larvae were photographed and the eggs were measured.

\section{RESULTS}

Presented below is a summary of the paleoparasitological findings available in the literature as well as the unpublished findings of our material. The data are separated by parasite and by chronological order. The archaeological site or the source mummy of the coprolite, country 


\section{TABLE I}

Origin of the samples examined at the Laboratory of Paleoparasitology of the Escola Nacional de Saúde PúblicaFundação Oswaldo Cruz, from January 2000 to July 2001

\begin{tabular}{lcc}
\hline $\begin{array}{l}\text { Origin of the } \\
\text { samples }\end{array}$ & $\begin{array}{c}\text { Samples } \\
\text { examined }\end{array}$ & $\begin{array}{c}\text { No. of } \\
\text { archaeological sites }\end{array}$ \\
\hline Brazil & 720 & 27 \\
Chile & 126 & 14 \\
USA & 20 & 1 \\
Argentina & 7 & 4 \\
Venezuela & 7 & $?$ \\
France & 5 & 2 \\
Peru & 4 & 1 \\
Germany & 3 & 1 \\
Belgium & 1 & 1 \\
Egypt & 1 & 1 \\
\hline
\end{tabular}

and date are given in Table II to Table XIV. Table XV shows non-intestinal human helminths. In Table XVI human paleoparasitological finds in the New and Old Worlds are shown, if pre or post-Columbian.

\section{DISCUSSION}

One of the most rich source of information about paleoecology is the analysis of ancient human droppings. The analysis of micro and macro remains like pollen, undigested seeds, fibers, small bones, scales and charcoal can reveal important aspects of diet, paleoclimate, agricultural development and prehistoric human occupation of ancient sites (Heizer \& Napton 1969, Wilke \& Hall 1975, Fry 1977, 1985, Reinhard \& Bryant Jr 1992). Dietary habits can also be inferred when parasites with intermediate host life cycles are found in coprolites and in latrine material (Callen \& Camaron 1960, Patrucco et al. 1983, Ferreira et al. 1984). Study of the coprolites in a paleontologic context can reveal interesting epidemiological patterns. Differences in parasitism between prehistorical hunter-gathering from agriculturalist population have been shown, related to sanitary patterns, type of dwelling and diet (Reinhard 1988a).

According to Darwin's theory, species have their origin in only one geographical area. Therefore, the utilization of parasites as biological markers allows a new approach concerning ancient human migrations. The dispersion of parasites in time can be used to trace migrations of their human hosts (Manter 1967, Araújo et al. 1988, Araújo \& Ferreira 1997). A better understanding of parasite distribution in ancient world made it also possible to speculate about the antiquity of human-parasite relationship (Araújo \& Ferreira 2000).

There are parasites that are specific to a host species and others that are not. Some parasites are found only in phylogenetically related host species. This kind of relationship began with a common ancient host species, early in time. There are species of parasites, however, that do not have such specificity, adapting themselves to several non-related hosts. Such parasites have been acquired by behavioral, social and biological changes, which have propitiated the host-parasite encounter, sometime during evolutionary history (Araújo et al. 2000). Enterobius vermicularis is an example of an inherited parasite, which has been present in human ancestors (Hugot et al. 1999), whereas Diphyllobothrium latum, for example, although a parasite found in ancient human populations, was acquired by food habits during the conquest of new habitats sometime in the past of mankind.

Helminths such as nematodes, cestodes, trematodes and acantocephalans keep their morphological parameters almost unchanged when $0.5 \% \mathrm{Na}_{3} \mathrm{PO}_{4}$ aqueous solution is employed to rehydrate desiccated organic remains (Confalonieri et al. 1985, Fry 1985). Protozoa cysts are identified too, although cysts suffer a faster decay, re-

TABLE II

Ancylostomid finds, locality, country and date from ancient remains

\begin{tabular}{|c|c|c|c|}
\hline Archaeological site/mummy & Country & Date & References \\
\hline Pedra Furada, Piauí & Brazil & $7230 \pm 80 \mathrm{BP}$ & Ferreira et al. 1987 \\
\hline Tiliviche, Iquique & Chile & $4100-1950 \mathrm{BC}$ & New finding \\
\hline Clairvaux, Jura & France & $3600 \mathrm{BC}$ & Dommelier-Espejo 2001 \\
\hline Boqueirão Soberbo, Minas Gerais & Brazil & $4905 \pm 85-1325 \pm 60 \mathrm{BP}$ & Ferreira et al. 1982 \\
\hline Chalain, Jura & France & $2700-2440 \mathrm{BC}$ & Dommelier-Espejo 2001 \\
\hline Daws Island, South Carolina ${ }^{a}$ & USA & $1700-1300 \mathrm{BC}$ & Rathbun et al. 1980 \\
\hline Hulin, Central Moravia & Czech Republic & $1600-1500 \mathrm{BC}$ & Šebela et al. 1990 \\
\hline Gentio Cave, Minas Gerais & Brazil & $3490 \pm 120-430 \pm 70 \mathrm{BP}$ & Ferreira et al. 1980, 1983 \\
\hline Toconao Oriente, San Pedro de Atacama & Chile & $2500-2100 \mathrm{BP}$ & New finding \\
\hline Big Bone Cave, Tennessee & USA & $2177 \pm 145 \mathrm{BP}$ & $\begin{array}{l}\text { Faulkner et al. 1989, } \\
\text { Faulkner \& Patton } 2001\end{array}$ \\
\hline Upper Salts Cave, Kentucky ${ }^{a}$ & USA & $1125-290 \mathrm{BC}$ & Dusseau \& Porter 1974 \\
\hline Valle Encantado, Neuquén & Argentina & $1000-500 \mathrm{BP}$ & New finding \\
\hline Tihuanaco & Peru & $890-950 \mathrm{AD}$ & Allison et al. 1974 \\
\hline Buldir Island, Alaska ${ }^{b}$ & USA & $1400-1700 \mathrm{AD}$ & Bouchet et al. 1999 \\
\hline Namur & Belgium & 18 th century AD & New finding \\
\hline Newport, Rhode Island & USA & 18th century AD & Reinhard et al. 1986 \\
\hline Sítio do Meio, Piauí & Brazil & Not available & New finding \\
\hline
\end{tabular}

$a$ : uncertain diagnosis; $b$ : human origin? 
TABLE III

Ascaris lumbricoides finds, locality, country and date from ancient remains

\begin{tabular}{|c|c|c|c|}
\hline Archaeological site/mummy & Country & Date & References \\
\hline Grand Grotte, Arcy-sur- Cure, Yonne & France & $30,160 \pm 140-24,660 \pm 330 \mathrm{BP}$ & Bouchet et al. 1996 \\
\hline Kruger Cave, Rustenburg ${ }^{a}$ & South Africa & $10,000-7000 \mathrm{BP}$ & Evans et al. 1996 \\
\hline Clairvaux, Jura ${ }^{a}$ & France & $3600 \mathrm{BC}$ & Dommelier-Espejo 2001 \\
\hline Arbon,Thurgau ${ }^{a}$ & Swiss & $3384-3370 \mathrm{BC}$ & Dommelier-Espejo 2001 \\
\hline Chalain, Jura $^{a}$ & France & $2700-2440 \mathrm{BC}$ & Dommelier-Espejo 2001 \\
\hline Huarmey Valley & Peru & $2277 \mathrm{BC} \pm 181$ & Patrucco et al. 1983 \\
\hline Somerset & England & $4100-2600 \mathrm{BP}$ & Jones \& Nicholson 1988 \\
\hline Hulin, Central Moravia & Czech Republic & $1600-1500 \mathrm{BC}$ & Šebela et al. 1990 \\
\hline Gentio Cave, Minas Gerais & Brazil & $3490 \pm 120-430 \pm 70 \mathrm{BP}$ & New finding \\
\hline Upper Salts Cave, Kentucky & USA & $1125-290 \mathrm{BC}$ & Fry 1974 \\
\hline Drobintz girl & Prussia & $600 \mathrm{BC}$ & Szidat 1944 \\
\hline Hallstatt & Austria & 2300 years & Aspöck et al. 1973 \\
\hline PUM II mummy & Egypt & $200 \mathrm{BC}$ & Cockburn et al. 1975 \\
\hline Big Bone Cave, Tennessee & USA & $2177 \pm 145 \mathrm{BP}$ & Faulkner et al. 1989 \\
\hline Hallein, Salzburg & Austria & 2000 years & Aspöck et al. 1974 \\
\hline Bremerhaven & Germany & $100 \mathrm{BC}-500 \mathrm{AD}$ & Jansen Jr \& Over 1962 \\
\hline Valkenburg on Rhine & Netherlands & $42-100 \mathrm{AD}$ & Jansen Jr \& Over 1966 \\
\hline Winchester $b$ & England & Roman Age & Pike 1968 \\
\hline Lindow Man & England & 2nd century AD & Jones 1986 \\
\hline Bobigny & France & 2nd century AD & Rousset et al. 1996 \\
\hline York $b$ & England & 2nd - 3rd century AD & Wilson \& Rackham 1976 \\
\hline Karwinden Man & Prussia & $500 \mathrm{AD}$ & Szidat 1944 \\
\hline Ribe & Denmark & $750-800 \mathrm{AD}$ & Nansen \& Jørgensen 1977 \\
\hline York & England & 9 th -10 th century AD & Jones 1982 \\
\hline Antelope House, Arizona & USA & $900-1250 \mathrm{AD}$ & new finding \\
\hline Elden Pueblo, Arizona & USA & $1070-1250 \mathrm{AD}$ & $\begin{array}{l}\text { Hevly et al. } 1979, \\
\text { Reinhard et al. } 1987\end{array}$ \\
\hline Winchester & England & 1000 years & Pike 1967a \\
\hline Winchester $b$ & England & $1100 \mathrm{AD}$ & Taylor 1955 \\
\hline Adak Island, Alaska & USA & $840 \pm 40 \mathrm{BP}$ & Bouchet et al. 2001 \\
\hline Acre & Israel & 13th century AD & Mitchell \& Stern 2000 \\
\hline Utrecht & Netherlands & 13th -14 th century AD & $\begin{array}{l}\text { Boersema \& Jansen 1975, } \\
\text { Jansen \& Boersema } 1982\end{array}$ \\
\hline Southampton & England & 13th -14 th century AD & Pike 1975 \\
\hline Amsterdam & Netherlands & $1370-1425 \mathrm{AD}$ & $\begin{array}{l}\text { Jansen \& Boersema 1972, } \\
\text { Jansen \& Boersema } 1982\end{array}$ \\
\hline Paris & France & 14 th -15 th century AD & Bouchet 1993, 1995 \\
\hline York & England & 14th - 16th century AD & $\begin{array}{l}\text { Jones et al. 1988, } \\
\text { Jones \& Nicholson } 1988\end{array}$ \\
\hline Worcester & England & 15 th century AD & Moore 1981 \\
\hline Oslo & Norway & 15 th century AD & Schia, 1979 \\
\hline Lübeck & Germany & 15 th century $\mathrm{AD}$ & $\begin{array}{l}\text { Herrmann 1985, } \\
\text { Herrmann \& Schulz } 1986\end{array}$ \\
\hline Montbeliard & France & 15 th -16 th century & new finding \\
\hline Schleswig & Germany & Medieval Age & Herrmann 1985 \\
\hline Berlin & Germany & Medieval Age & Herrmann 1985 \\
\hline Braunschweig & Germany & Medieval Age & Herrmann 1985 \\
\hline Hameln & Germany & Medieval Age & Herrmann 1985 \\
\hline Höxter & Germany & Medieval Age & Herrmann 1985 \\
\hline Göttingen & Germany & Medieval Age & Herrmann 1985 \\
\hline Marburg & Germany & Medieval Age & Herrmann 1985 \\
\hline Freiburg & Germany & Medieval Age & Herrmann 1985 \\
\hline Breisach & Germany & Medieval Age & Herrmann 1985 \\
\hline Regensburg & Germany & Medieval Age & Herrmann 1985 \\
\hline Landshut & Germany & Medieval Age & Herrmann 1985 \\
\hline Newfoundland $b$ & Canada & 17 th century AD & Horne \& Tuck 1996 \\
\hline Marly-le-Roy, Yveline ${ }^{b}$ & France & 17 th -18 th century $A D$ & Bouchet et al. 1998 \\
\hline Williamsburg, Virginia & USA & $1720 \mathrm{AD}$ & Reinhard 1990 \\
\hline Namur & Belgium & 18th century AD & New finding \\
\hline Newport, Rhode Island & USA & 18th century AD & Reinhard et al. 1986 \\
\hline Wellington & New Zealand & 150 - 200 years & Andrews 1976 \\
\hline
\end{tabular}

$a$ : uncertain diagnosis; $b$ : human origin? 
sulting in artificially low estimations of protozoa as indicated by the infrequent finding of protozoan cysts in coprolites (Gonçalves et al. 2002).

In a review, the correct identification of the origin of the specimens poses special problem in the validity of data. When the coprolites are not obtained from a mummified body, it can be difficult to ascertain its origin. The same problem arises when analyzing sediment from latrines. It is possible of misdiagnosis between human and wild or domestic animal fecal material (Fry 1977, 1985, Reinhard \& Bryant Jr 1982).

But, if there is no absolute test to determinate the zoological fecal origin, there are some well established criteria for differentiation between human and non-human coprolites. It is possible to select human coprolites based in their size, shape, macro and micro contents, and most important, parasites. The finding of an exclusive human helminth in a sample clearly indicates their origin (Reinhard $\&$ Bryant Jr 1982, Fry 1985). When that is not the case, the parasite egg size is a valuable tool to indicate the coprolite origin (Confalonieri et al. 1985).

Interpretation of some parasitic findings can be troublesome. False parasitism should always be considered when eggs from a non-human parasite are recovered in a supposed human coprolite (Taylor 1955). These eggs may have been introduced in human digestive tract by consumption of some definitive parasite host. Zimmerman (1980) reported the finding of eggs from Cryptocotyle lingua, a fish trematode, in a 1,600 year old frozen Eskimo mummy. Although eggs from this trematode have been recovered from modern Eskimos, the adult helminth has never been found in humans. Similarly, Eimeria sp., probably E. mira, a protozoa of red squirrel, has been found in the intestine of the Bog Man from Grauballe, dated between 1540 and 1740 years BP (Before Present). It appears to be due to the ingestion of contaminated meat or offal (Hill 1990). The finding of Capillaria spp., a rodent parasite, in human coprolites have been reported (Bouchet 1997). Although very rare in humans, the presence of Capillaria eggs in feces may actually indicate the ingestion of an infected liver (Roberts \& Janovy Jr 2000). Coimbra Jr and Mello (1981) reported the finding of Capillaria eggs in feces of two Indians from the Amazonian region, probably resulting from the habit of animal liver ingestion.

Necator americanus and Ancylostoma duodenale are the most frequent ancylostomid parasitizing humans. The former was more frequent in Southern Africa, in the Americas, and in the Pacific Islands. A. duodenale was common in northern hemisphere, mainly in southern Europe, northern Africa, in India, in China and in southeastern Asia. But now, as a result of the large human movements throughout the world, their geographic distributions are quite ubiquitous. The worms mature and mate in the small intestine of the host. Eggs, passed with feces, hatch in environment if adequate moisture, shade and warm soil are found. The newly hatched larvae go on to develop eventually into the infective filariform larvae. The life-span of $N$. americanus and A. duodenale varies from 4 to 5 years and from 6 to 8 years respectively (Roberts \& Janovy Jr 2000, Rey 2001). The species can not be diag- nosed reliably when the only remains are eggs, as most cases in coprolites or latrine sediment. Differentiation of A. duodenale from N. americanus larvae is difficult, especially in rehydrated material.

Ancylostomids have been found in archaeological sites from both New and Old Worlds (Table II). Most finds are from the Americas. Human infection has been present in Amerindians far before Columbus. It strongly suggests some kind of transoceanic contact before $7230 \pm 80$ years ago (the oldest finding by now) (Araújo et al. 1988, Araújo $\&$ Ferreira 1997). Ancylostomids, as well as other helminths that require warm and moist conditions to complete their life cycles outside their host, could not have survived during human migration by land through Bering Strait during the last ice age. Coastal navigation along the southern coast of the Bering Land Bridge is a more feasible route (Dixon 2001). Paleoparasitological finds from that region could support this alternative pathway of peopling of the New World. Unfortunately, from a paleoparasitological view, most ancient coastal areas are currently underwater, due to the rise of oceanic water levels after the Ice Age.

Ascaris is a cosmopolitan helminth. Adult worms live in the small intestine of the host, and, as the ancylostomids, passed eggs need suitable environment to continue development. But Ascaris eggs can remain viable in soil for some years, even under tough conditions. The adult life time is estimated to be 2 years (Rey 2001). Table III shows a very wide distribution of A. lumbricoides in the Old World, especially in the Middle Ages. It reflects poor sanitation and high population density in enlarging villages.

A. lumbricoides and A. suum are morphologically and physiologically similar. They parasitize humans and pigs respectively. It has been suggested that a common ancestor of A. lumbricoides and A. suum originally parasitized pigs. Later, this ascarid adapted to humans when pigs were domesticated. But that is still an unsolved question (Roberts \& Janovy Jr 2000). The finding of A. lumbricoides eggs in France (Table III), much earlier than the time of pig domestication, nearly 9000 years ago (Giuffra et al. 2000), suggests that humans were first parasitized. After pig domestication, the parasite adapted to pigs. Similar findings in the New World in pre-European context also suggest this.

Trichuris trichiura adult worms live in the colon and is also a cosmopolitan parasite. Some 70 species of Trichuris have been reported from a wide variety of mammals. T. trichiura parasitizes humans, and as ancylostomids and Ascaris, warmth and moisture are necessary to fully develop the embryos (Roberts \& Janovy Jr 2000). T. trichiura lifetime is estimated to be up to 6-8 years (Rey 2001). The egg size sometimes can be a reliable tool for identifying the species of Trichuris in coprolites of unknown origin (Confalonieri et al. 1985). Paleoparasitological findings (Table IV) show its wide distribution, including the New World in pre-Columbian times. As A. lumbricoides, the wide distribution of T. trichiura in the Antiquity and in the Middle Ages, reflects human living conditions. For unknown reasons the findings of $T$. trichuris in the New World are more frequent than the findings of A. lumbricoides. 
TABLE IV

Trichuris trichiura finds, locality, country and date from ancient remains

\begin{tabular}{|c|c|c|c|}
\hline Archaeological site/mummy & Country & Date & References \\
\hline Kruger Cave, Rustenburg ${ }^{a}$ & South Africa & $10,000-7000 \mathrm{BP}$ & Evans et al. 1996 \\
\hline Lapa Pequena, Minas Gerais & Brazil & $8000-7000 \mathrm{BP}$ & New finding \\
\hline Clairvaux, Jura & France & $3600-3500 \mathrm{BC}$ & Dommelier-Espejo 2001 \\
\hline Swifterbant ${ }^{a}$ & Netherlands & $5400 \pm 40-5230 \pm 40 \mathrm{BP}$ & Roever-Bonnet et al. 1979 \\
\hline Arbon, Thurgau & Swiss & $3384-3370 \mathrm{BC}$ & Dommelier-Espejo 2001 \\
\hline Otzal, Tyrol & Austria & $3300-3200 \mathrm{BC}$ & Aspöck et al. 1996 \\
\hline Chalain, Jura & France & $32 \mathrm{nd}-25$ th century BC & $\begin{array}{l}\text { Bouchet et al. 1995, } \\
\text { Dommelier et al. 1998, } \\
\text { Dommelier-Espejo 2001 }\end{array}$ \\
\hline Boqueirão Soberbo, Minas Gerais & Brazil & $4905 \pm 85-1325 \pm 60 \mathrm{BP}$ & Ferreira et al. 1982 \\
\hline Somerset & England & $4100-2600 \mathrm{BP}$ & Jones \& Nicholson 1988 \\
\hline Santa Elina, Mato Grosso & Brazil & $4000-2000 \mathrm{BP}$ & New finding \\
\hline Hulin, Central Moravia & Czech Republic & $1600-1500 \mathrm{BC}$ & Šebela et al. 1990. \\
\hline Gentio Cave, Minas Gerais & Brazil & $3490 \pm 120-430 \pm 70 \mathrm{BP}$ & Ferreira et al. 1980, 1983 \\
\hline Tulán, San Pedro de Atacama & Chile & $1080-950 \mathrm{BC}$ & New finding \\
\hline Drobintz girl & Prussia & $600 \mathrm{BC}$ & Szidat 1944 \\
\hline Jerusalem & Middle East & 7th - 6th century BC & Cahill et al. 1991 \\
\hline Chu Dynasty mummy, Hubei province & China & 2300 years & Yang et al. 1984 \\
\hline Hallstatt & Austria & 2300 years & Aspöck et al. 1973 \\
\hline Tollund Man, Central Jutland & Denmark & $210 \mathrm{BC}$ & Helbaek 1958 \\
\hline Han Dynasty mummy, Hubei province & China & $167 \mathrm{BC}$ & $\begin{array}{l}\text { Liangbiao \& Tao 1981, } \\
\text { Cheng } 1984\end{array}$ \\
\hline Vilshofen & Germany & $150-140 \mathrm{BC}$ & Specht 1963 \\
\hline Bremerhaven & Germany & $100 \mathrm{BC}-500 \mathrm{AD}$ & Jansen Jr \& Over 1962 \\
\hline Han Dynasty mummy, Hunam province & China & $2100 \mathrm{BP}$ & Wei 1973 \\
\hline Estrago Cave, Pernambuco & Brazil & $2000 \mathrm{BP}$ & Ferreira et al. 1989a \\
\hline Hallein, Salzburg & Austria & 2000 years & Aspöck et al. 1974 \\
\hline Valkenburg on Rhine & Netherlands & $42-100 \mathrm{AD}$ & Jansen Jr \& Over 1966 \\
\hline Winchester $a, b$ & England & Roman Age & Pike 1968 \\
\hline Lindow Man, Manchester & England & 2nd century AD & Jones 1986 \\
\hline Bobigny & France & 2nd century $\mathrm{AD}$ & Rousset et al. 1996 \\
\hline Nahal-Mishmar Valley & Israel & $160 \mathrm{AD}$ & Witenberg 1961 \\
\hline York & England & 2nd - 3rd century AD & Wilson \& Rackham 1976 \\
\hline Grauballe Man, Silkeborg & Denmark & 3rd - 4th century AD & Helbaek 1958 \\
\hline Karwinden Man & Prussia & $500 \mathrm{AD}$ & Szidat 1944 \\
\hline Ribe & Denmark & $750-800 \mathrm{AD}$ & Nansen \& Jørgensen 1977 \\
\hline York & England & 9 th -11 th century AD & $\begin{array}{l}\text { Hall et al. 1983, } \\
\text { Jones } 1982\end{array}$ \\
\hline Huarmey Valley & Peru & $1000 \mathrm{AD}$ & Patrucco et al. 1983 \\
\hline Winchester & England & 11 th century $\mathrm{AD}$ & $\begin{array}{l}\text { Pike 1967a, } \\
\text { Pike \& Biddle } 1966\end{array}$ \\
\hline Elden Pueblo, Arizona & USA & $1070-1250 \mathrm{AD}$ & $\begin{array}{l}\text { Hevly et al. } 1979, \\
\text { Reinhard et al. } 1987\end{array}$ \\
\hline Winchester $^{a}$ & England & $1100 \mathrm{AD}$ & Taylor 1955 \\
\hline Acre & Israel & 13th century AD & Mitchell \& Stern 2000 \\
\hline Southampton & England & 13th -14 th century AD & Pike 1975 \\
\hline Utrecht & Netherlands & 13th -14 th century AD & $\begin{array}{l}\text { Boersema \& Jansen 1975, } \\
\text { Jansen \& Boersema } 1982\end{array}$ \\
\hline Paris & France & 14 th -15 th century AD & Bouchet 1993,1995 \\
\hline York & England & 14th - 16th century AD & $\begin{array}{l}\text { Jones \& Nicholson 1988, } \\
\text { Hall et al. } 1983\end{array}$ \\
\hline Amsterdam & Netherlands & $1370-1425 \mathrm{AD}$ & $\begin{array}{l}\text { Jansen \& Boersema 1972, } \\
\text { Jansen \& Boersema } 1982\end{array}$ \\
\hline Worcester & England & 15th century AD & Moore 1981 \\
\hline Lübeck & Germany & 15 th century AD & Herrmann \& Schulz 1986 \\
\hline Oslo & Norway & 15th century AD & Schia 1979 \\
\hline Schleswig & Germany & Medieval Age & Herrmann 1985 \\
\hline Lübeck & Germany & Medieval Age & Herrmann 1985 \\
\hline Berlin & Germany & Medieval Age & Herrmann 1985 \\
\hline Braunschweig & Germany & Medieval Age & Herrmann 1985 \\
\hline Hameln & Germany & Medieval Age & Herrmann 1985 \\
\hline Höxter & Germany & Medieval Age & Herrmann 1985 \\
\hline
\end{tabular}




\begin{tabular}{llll}
\hline Archaeological site/mummy & Country & Date & References \\
\hline Göttingen & Germany & Medieval Age & Herrmann 1985 \\
Marburg & Germany & Medieval Age & Herrmann 1985 \\
Freiburg & Germany & Medieval Age & Herrmann 1985 \\
Breisach & Germany & Medieval Age & Herrmann 1985 \\
Regensburg & Germany & Medieval Age & Herrmann 1985 \\
Landshut & Germany & Medieval Age & Pizzi \& Schenone 1954 \\
Cerro El Plomo, Santiago & Chile & pre-Columbian & Pike 1967b \\
Inca mummy & & ca. 1500 AD & New finding \\
Montbeliard & France & 15th - 16th century AD & Fouant et al. 1982 \\
Murga culture & Peru & Colonial period & Horne \& Tuck 1996 \\
Newfoundland $a$ & Canada & 17th century AD & Bouchet et al. 1998 \\
Marly-le -Roy, Yveline $a$ & France & 17th - 18th century AD & Reinhard 1990 \\
Williamsburg, Virginia & USA & 1720 AD & Confalonieri et al. 1981 \\
Itacambira, Minas Gerais & Brazil & 18th century AD & Reinhard et al. 1986 \\
Newport, Rhode Island & USA & 18th century AD & New finding \\
Namur & Belgium & 18th century AD & Reinhard 1990 \\
New York City, New York & USA & 19th century AD & Faulkner et al. 2000 \\
Fayette, Michigan & USA & 19th century AD & New finding \\
Pedra Furada, Piauí & Brazil & not available & \\
\hline
\end{tabular}

$a$ : human origin?; $b$ : Capillaria $\mathrm{sp.?}$

Enterobius vermicularis is an exclusive human parasite. Organic material containing eggs of this parasite should be of human origin. As A. lumbricoides, E. vermicularis is cosmopolitan. The adults live mostly in the ileocecal region. The eggs are passed by migrating adult females in the anus and peri-anal area. The eggs can directly infect other host, either by fecal-oral route as through airborne inhaled and swallowed eggs. Its life time is estimated to be up to 2 months (Roberts \& Janovy Jr 2000, Rey 2001). For unknown reasons, the finding of $E$. vermicularis in archaeological material outside the New World is scarce (Table V). A hypothetical origin of this parasite in the Americas can be ruled out. E. vermicularis has a long history of coevolution with its human host. They have been coexisting together in Africa long time before human dispersion throughout the continents (Ferreira et al. 1997, Hugot et al. 1999).

Strongyloides stercoralis parasitizes humans, other primates, dogs, cats, and some other mammals. It is a parasite of tropical regions, although also found in temperate areas of the world. Having a complex life cycle, with a free-living larvae stage, the female adult worm lives in the small intestine of the host. The eggs usually hatches in the intestinal host lumen. The resulting larvae are passed in feces (Roberts \& Janovy Jr 2000, Rey 2001). Table VI shows the findings of $S$. stercoralis in archaeological material. Caution should be exerted in diagnosing this parasite in sediment or coprolites. Free-living and ancylostomid larvae can be misidentified.

Many species of Trichostrongylus parasitize the small intestine of many mammals and birds. Some species can infect humans. In some areas in Asia and Africa they are very frequent. In southwest Iran and in a village in Egypt, up to $70 \%$ of human population have been found infected (Roberts \& Janovy Jr 2000). Trichostrongylus eggs are remarkably similar to those of ancylostomids, but usually are larger. Human infection have been detected only in the Americas up to now (Table VI).

Fasciola hepatica is a helminth of cattle and sheep. Human infection occurs occasionally, mainly in certain areas of Europe, Africa and Latin America. The adult worm lives in the bile ducts of the host, passing eggs in feces. The eggs hatch in fresh water, and the parasite completes its life cycle in a snail. Infection occurs by ingestion of metacercaria in vegetation or in water. Occasionally human infections with other Fasciola species occur (Roberts \& Janovy Jr 2000, Rey 2001). Human infection with Fasciola spp. have been detected in coprolites and ancient latrines sediment after herding begun (Table VII), and until now only in the Old World paleofeces.

Three species of Schistosoma have major medical importance: S. haematobium, S. japonicum and S. mansoni. Only S. mansoni is found in the New World. S. haematobium is found mainly in Africa and Near East. S. japonicum is found in southeastern Asia and west Pacific. S. mansoni is found mainly in Brazil, Caribbean and Africa. Adult worms of S. haematobium live in veins of urinary bladder plexus of the host, so eggs are passed in the urine. Adult worms of S. japonicum and S. mansoni live in intestinal veins, and their eggs are passed in the feces. The eggs of Schistosoma spp. hatch in fresh water and the parasite complete its life cycle in a snail. Infection occurs when the parasite penetrates through the host skin (Roberts \& Janovy Jr 2000, Rey 2001). Table VIII shows that the findings of Schistosoma spp. reflect in some degree their modern distribution, except the Americas in regard to $S$. mansoni. The findings in medieval Europe latrines reflects imported cases from Africa, since there is no intermediate host in Europe.

Dicrocoelium dendriticum is a frequent parasite of ruminants. Rarely it is found in humans. The cycle is somewhat similar to that of Fasciola, but there are two inter- 
TABLE V

Enterobius vermicularis finds, locality, country and date from ancient remains

\begin{tabular}{|c|c|c|c|}
\hline Archaeological site/mummy & Country & Date & References \\
\hline Danger Cave, Utah & USA & $7837 \mathrm{BC} \pm 630$ & $\begin{array}{l}\text { Fry \& Hall } 1969, \\
\text { Fry \& Moore } 1969\end{array}$ \\
\hline Dirty Shame rockshelter, Oregon & USA & 6,300 years & Hall 1976 \\
\hline Tiliviche, Iquique & Chile & $4100-1950 \mathrm{BC}$ & New finding \\
\hline Hogup Cave, Utah & USA & $4010 \mathrm{BC}-1 \mathrm{AD}$ & $\begin{array}{l}\text { Fry \& Hall } 1969, \\
\text { Fry \& Moore } 1969\end{array}$ \\
\hline Huarmey Valley & Peru & $2277 \mathrm{BC} \pm 181$ & Patrucco et al. 1983 \\
\hline Hinds Cave,Texas & USA & $2100-600 \mathrm{BC}$ & Reinhard 1988b \\
\hline Tulán, San Pedro Atacama & Chile & $1080-950 \mathrm{BC}$ & Ferreira et al. 1989b \\
\hline Caserones, Tarapaca Valley & Chile & $400 \mathrm{BC}-800 \mathrm{AD}$ & Araujo et al. 1985 \\
\hline Clyde's Cavern, Utah & EUA & 2300 years & Hall 1972 \\
\hline Big Bone Cave, Tennessee & EUA & $2177 \pm 145 \mathrm{BP}$ & Faulkner et al. 1989 \\
\hline Han Dynasty mummy, Hunam province & China & 2100 years & Wei 1973 \\
\hline Turkey Pen Cave, Utah & USA & 1600 years & Reinhard et al. 1987 \\
\hline Clyde's Cavern, Utah & USA & $460-1500 \mathrm{AD}$ & Hall 1972 \\
\hline Canyon del Muerto, Arizona & USA & $600 \mathrm{AD} \pm 95$ & El-Najjar et al. 1980 \\
\hline Rio Zape, Durango & Mexico & $600 \mathrm{AD}$ & Reinhard et al. 1989 \\
\hline Big Horn Sheep Ruin, Utah & USA & $900-1250 \mathrm{AD}$ & Gardner \& Clary 1987 \\
\hline Mesa Verde, Arizona & USA & $900-1250 \mathrm{AD}$ & Stiger 1977 \\
\hline Chaco Canyon, New Mexico & USA & $920-1200 \mathrm{AD}$ & $\begin{array}{l}\text { Reinhard et al. 1987, } \\
\text { Reinhard \& Clary } 1986\end{array}$ \\
\hline Wetherill Mesa, Colorado & USA & 1000 years & Samuels 1965 \\
\hline Elden Pueblo, Arizona & USA & $1070-1250 \mathrm{AD}$ & $\begin{array}{l}\text { Hevly et al. } 1979, \\
\text { Reinhard et al. } 1987\end{array}$ \\
\hline Antelope House, Arizona & USA & $1075-1250 \mathrm{AD}$ & $\begin{array}{l}\text { Fry \& Hall } 1975, \\
\text { Reinhard et al. } 1987\end{array}$ \\
\hline Salmon Ruin, New Mexico & USA & $1200-1275 \mathrm{AD}$ & Reinhard et al. 1987 \\
\hline Inscription House, Arizona & USA & $1250-1300 \mathrm{AD}$ & Fry \& Hall 1973 \\
\hline Göttingen & Germany & Medieval Age & Herrmann 1985 \\
\hline Greenland & Denmark & $1475 \mathrm{AD} \pm 50$ & Hansen 1986 \\
\hline Pie de Palo & Argentina & pre-Columbian & Zimmerman \& Morilla 1983 \\
\hline
\end{tabular}

TABLE VI

Other Nematode finds, locality, country and date from ancient remains

\begin{tabular}{|c|c|c|c|}
\hline Archaeological site/mummy & Country & Date & References \\
\hline \multicolumn{4}{|l|}{ Strongyloides stercoralis } \\
\hline Asru mummy & Egypt & ca. $1000 \mathrm{BC}$ & Tapp 1979 \\
\hline Clyde's Cavern, Utah ${ }^{a}$ & USA & $400-1200 \mathrm{AD}$ & Hall 1972 \\
\hline Chaco Canyon, New Mexico ${ }^{a}$ & USA & $920-1130 \mathrm{AD}$ & Reinhard \& Clary 1986 \\
\hline Antelope House, Arizona ${ }^{a}$ & USA & $1175-1250 \mathrm{AD}$ & Reinhard et al. 1987 \\
\hline Amsterdam $^{a}$ & Netherlands & $1370-1425 \mathrm{AD}$ & Jansen \& Boersema 1972 \\
\hline \multicolumn{4}{|l|}{ Trichostrongylus spp. } \\
\hline Dust Devil Cave, Utah ${ }^{a}$ & USA & $6800-4800 \mathrm{BC}$ & Reinhard et al. 1985 \\
\hline Tulán, San Pedro de Atacama & Chile & $1080-950 \mathrm{BC}$ & New finding \\
\hline Rio Zape, Durango ${ }^{a}$ & Mexico & $600 \mathrm{AD}$ & Reinhard et al. 1989 \\
\hline Valle Encantado, Neuquén & Argentina & $1000-500 \mathrm{BP}$ & New finding \\
\hline Antelope House, Arizona & USA & $1175-1250 \mathrm{AD}$ & Reinhard et al. 1987 \\
\hline Catarpe 2, San Pedro de Atacama ${ }^{a}$ & Chile & $1450-1525 \mathrm{AD}$ & New finding \\
\hline Itacambira, Minas Gerais & Brazil & 18th century AD & Araujo et al. 1984 \\
\hline
\end{tabular}

$a$ : uncertain diagnosis 
mediate hosts, a terrestrial snail and an ant. Although cases of true parasitism occur in humans, many reported cases of human infection are actually false parasitism, as eggs can be found in feces resulting from a recent liver repast (Taylor 1955, Roberts \& Janovy Jr 2000). It is virtually impossible to distinguish true and false human parasitism when the only ancient host remains are feces.

Clonorchis sinensis is found in southeastern Asia. It is a parasite of human and some other mammals. The adult fluke also lives in the host bile duct. The eggs are passed in the feces and the parasite completes its life cycle in two intermediate hosts, a snail and some species of fish and crustaceans. The definitive host is infected by eating raw or undercooked fish (Roberts \& Janovy Jr 2000). Ancient infection by $C$. sinensis has only been found in mummified corpses from China (Table IX).

Two species of Taenia are frequent human intestinal parasites. T. saginata, the most frequent, is found in al- most all countries where beef is eaten. T. solium is endemic in Latin America, Africa and some Asian countries. Intermediate hosts of $T$. saginata and $T$. solium are cattle and pigs, respectively. In $T$. solium infection, human can be both intermediate and definite host. Infection occurs when one eats infected beef or pork. Eggs are passed in the human feces (Roberts \& Janovy Jr 2000, Rey 2001). In paleoparasitologic analysis, most often the only egg structure found is the oncosphere. In this case it is not possible to distinguish between the two different species of Taenia that infect humans. As expected, Taenia spp. have not been found in the New World in pre-Columbian time (Table X). Pork and beef were not available.

$D$. latum and D. pacificum are parasites of fish-eating mammals. The former is mostly found in Europe and North America whereas D. pacificum is found mostly in the pacific coast of South America. Diphyllobothrium spp. have two intermediate hosts, copepods and fishes. Living in

TABLE VII

Fasciola spp. finds, locality, country and date from ancient remains

\begin{tabular}{|c|c|c|c|}
\hline Archaeological site/mummy & Country & Date & References \\
\hline Clairvaux, Jura & France & $3600 \mathrm{BC}$ & Dommelier-Espejo 2001 \\
\hline Swifterbant $^{a}$ & Netherlands & $5400 \pm 40-5230 \pm 40 \mathrm{BP}$ & Roever-Bonnet et al. 1979 \\
\hline Arbon, Thurgau & Swiss & $3384-3370 \mathrm{BC}$ & Dommelier-Espejo 2001 \\
\hline Chalain, Jura ${ }^{b}$ & France & 32 nd -25 th century BC & $\begin{array}{l}\text { Bouchet et al. 1995, } \\
\text { Dommelier et al. } 1998\end{array}$ \\
\hline Saale-Unstrut Valley $b$ & Germany & $2500 \mathrm{BC}$ & Dittmar \& Teegen 2000 \\
\hline Lovelock Cave, Nevada ${ }^{c}$ & USA & $500 \mathrm{BC}-1150 \mathrm{AD}$ & Dunn \& Watkins 1970 \\
\hline Bremerhaven $b$ & Germany & $100 \mathrm{BC}-500 \mathrm{AD}$ & Jansen Jr \& Over 1962 \\
\hline Hallein, Salzburg ${ }^{b}$ & Austria & 2000 years & Aspöck et al. 1974 \\
\hline Ribe $^{b}$ & Denmark & $750-800 \mathrm{AD}$ & Nansen \& Jørgensen 1977 \\
\hline Odra river $b, d$ & Poland & 10 th -13 th century AD & Grzywinski 1960 \\
\hline Paris ${ }^{b}$ & France & 14 th -15 th century AD & Bouchet 1993, 1995 \\
\hline Lübeck & Germany & 15 th century $\mathrm{AD}$ & $\begin{array}{l}\text { Herrmann 1985, } \\
\text { Herrmann \& Schulz } 1986\end{array}$ \\
\hline Braunschweig & Germany & Medieval Age & Herrmann 1985 \\
\hline Hameln & Germany & Medieval Age & Herrmann 1985 \\
\hline Freiburg & Germany & Medieval Age & Herrmann 1985 \\
\hline Marly-le -Roy, Yveline ${ }^{a}$ & France & 17 th -18 th century AD & Bouchet et al. 1998 \\
\hline
\end{tabular}

$a$ : human origin?; $b$ : Fasciola hepatica; $c$ : uncertain diagnosis; $d$ : non-human origin?

TABLE VIII

Schistosoma spp. finds, locality, country and date from ancient remains

\begin{tabular}{|c|c|c|c|}
\hline Archaeological site/mummy & Country & Date & References \\
\hline Mummies $a$ & Egypt & $3200 \mathrm{BC}$ and $1198-1150 \mathrm{BC}$ & Deelder et al. 1990 \\
\hline Mummy, Tumb of Parannefer ${ }^{a}$ & Egypt & $1450 \mathrm{BC}$ & Horne \& Redford 1995 \\
\hline 20 th dynasty mummies ${ }^{a}$ & Egypt & $1250-1000 \mathrm{BC}$ & Ruffer 1910 \\
\hline Nakht - ROM I mummy ${ }^{a}$ & Egypt & $3200 \mathrm{BP}$ & Reyman et al. 1977 \\
\hline Han Dynasty mummy, Hubei province ${ }^{b}$ & China & $167 \mathrm{BC}$ & $\begin{array}{l}\text { Liangbiao \& Tao 1981, } \\
\text { Cheng } 1984\end{array}$ \\
\hline Han Dynasty mummy, Hunam province ${ }^{b}$ & China & $2100 \mathrm{BP}$ & Wei 1973 \\
\hline Mummies ${ }^{a}$ & Sudan & $350-550 \mathrm{AD}$ & Miller et al. 1992 \\
\hline Montbéliard ${ }^{a}$ & France & 15 th century $\mathrm{AD}$ & Bouchet \& Paicheler 1995 \\
\hline Montbéliard ${ }^{c}$ & France & 15th -16 th century AD & Bouchet et al. 2002 \\
\hline
\end{tabular}

a: Schistosoma haematobium; $b$ : S. japonicum; $c$ : S. mansoni 
the host intestine, eggs are passed in feces (Roberts \& Janovy Jr 2000, Rey 2001). Human infections with $D$. pacificum and $D$. latum result from the ingestion of raw or undercooked marine and fresh water fishes respectively. Table XI shows that eggs found in archaeological material reflects the modern distribution of Diphyllobothrium spp. It is related to the habits of fish consumption by humans.

Although rare, seven species of the phylum Acanthocephala have been reported parasiting human hosts. This phylum accomplishes parasites of fishes, birds, amphibians, mammals, and reptiles. At least two hosts are necessary to complete their life cycle. Depending on the species involved, the first host is an insect, crustacean or myriapod. The definite host passes eggs in the feces (Roberts \& Janovy Jr 2000). Ancient human infection have been detected only in the Americas, mainly in USA (Table XIII), probably reflecting insect-eating habits.

The intestinal Protozoa usually live inside the host in the intestinal lumen or inside the intestinal epithelial cells. The infective stage are cysts or oocysts. They are passed in the host feces. Humans most often are parasitized with Entamoeba spp. and Giardia duodenalis (Roberts \& Janovy Jr 2000, Rey 2001). Cysts are not so resistant to decay as helminth eggs are. So, reliable findings of protozoa in coprolites and cesspit material are very rare (Table XIV). But some protozoa glycoprotein antigen, detectable by immunologic test, can still be found, even centu-

TABLE IX

Other Trematode finds, locality, country and date from ancient remains

\begin{tabular}{|c|c|c|c|}
\hline Archaeological site/mummy & Country & Date & References \\
\hline \multicolumn{4}{|l|}{ Dicrocoelium spp. } \\
\hline Arbon, Thurgau & Swiss & $3384-3370 \mathrm{BC}$ & Dommelier-Espejo 2001 \\
\hline Chalain, Jura & France & $3040-3000 \mathrm{BC}$ & Dommelier-Espejo 2001 \\
\hline Hallein, Salzburg & Austria & 2000 years & Aspöck et al. 1974 \\
\hline Winchester ${ }^{a}$ & England & Roman Age & Pike 1968 \\
\hline Winchester ${ }^{b}$ & England & 11 th century $\mathrm{AD}$ & $\begin{array}{l}\text { Pike \& Biddle 1966, } \\
\text { Pike 1967a }\end{array}$ \\
\hline Winchester $b, c$ & England & $1100 \mathrm{AD}$ & Taylor 1955 \\
\hline Paris $b$ & France & 14 th -15 th century AD & Bouchet 1993, 1995 \\
\hline Newfoudland $a, b$ & Canada & 17 th century AD & Horne \& Tuck 1996 \\
\hline \multicolumn{4}{|l|}{ Opisthorchiformes } \\
\hline Swifterbant ${ }^{a}$ & Netherlands & $5400 \pm 40-5230 \pm 40 \mathrm{BP}$ & Roever-Bonnet et al. 1979 \\
\hline Arbon, Thurgau & Swiss & $3384-3370 \mathrm{BC}$ & Dommelier-Espejo 2001 \\
\hline Chu Dynasty mummy, Hubei province ${ }^{d}$ & China & 2300 years & Yang et al. 1984 \\
\hline Han Dynasty mummy, Hubei province ${ }^{d}$ & China & $167 \mathrm{BC}$ & $\begin{array}{l}\text { Liangbiao \& Tao 1981, } \\
\text { Cheng } 1984\end{array}$ \\
\hline Glenn Canyon, Utah $c ?$ & USA & $1250 \mathrm{AD}$ & Moore et al. 1974 \\
\hline \multicolumn{4}{|l|}{ Paragonimus sp. } \\
\hline Atacama desert & Chile & $2500 \mathrm{BC}$ & Hall 1976 \\
\hline
\end{tabular}

$a$ : unknown origin; $b$ : Dicrocoelium dendriticum; $c$ : false parasitism; $d$ : Clonorchis sinensis

TABLE X

Taenia spp. finds, locality, country and date from ancient remains

\begin{tabular}{llll}
\hline Archaeological site/mummy & Country & Date & References \\
\hline $\begin{array}{lll}\text { Nakht - ROM I mummy } \\
\text { Chalain, Jura }\end{array}$ & Egypt & 3200 BP & Reyman et al. 1977 \\
Jerusalem & France & 32nd - 25th century BC & $\begin{array}{l}\text { Dommelier et al. 1998, } \\
\text { Dommelier-Espejo 2001 } \\
\text { Han Dynasty mummy, Hubei province }\end{array}$ \\
& Middle East & 7th - 6th century BC & $\begin{array}{l}\text { Cahill et al. 1991 } \\
\text { Liangbiao \& Tao 1981, } \\
\text { Cheng 1984 }\end{array}$ \\
$\begin{array}{ll}\text { Bremerhaven } \\
\text { Hallein, Salzburg }\end{array}$ & Germany & 167 BC & Jansen Jr \& Over 1962 \\
Ribe & Austria & 2000 years & Aspöck et al. 1974 \\
Amsterdam & Denmark & $750-800$ AD & Nansen \& Jørgensen 1977 \\
Göttingen & Netherlands & $1370-1425$ AD & Jansen \& Boersema 1972 \\
Newfoundland & Germany & Medieval Age & Herrmann 1985 \\
Marly-le-Roy, Yveline & Canada & 17th century AD & Horne \& Tuck 1996 \\
\hline
\end{tabular}

a: Taenia solium 
ries after these parasites have been passed in feces. Gonçalves et al. (2002) detected G. duodenalis antigen by monoclonal antibody immunosorbant assay in samples dated to about $1200 \mathrm{AD}, 1600 \mathrm{AD}$ and $1700 \mathrm{AD}$, in coprolites and latrine soil from USA and Europe. Only one sample was positive to directed microscopic examination.

Paleoparasitological analysis of human mummies, human coprolites and cesspit material have been demonstrating the diversity and antiquity of human parasitism. In Africa, the following parasites have been detected in ancient human feces: S. stercoralis, S. haematobium, Taenia spp., Echinococcus granulosus, Trichinella spiralis, Dracunculus medinensis, filarial worm, and possibly $A$. lumbricoides and T. trichiura. In Europe, ancylostomids, A. lumbricoides, T. trichiura, E. vermicularis, Fasciola spp., F. hepatica, S. mansoni, S. haematobium, Dicrocoelium spp., D. dendriticum, Opisthorchiformes, Taenia spp., Diphyllobothrium spp., D. latum, G. duodenalis, E. granulosus, $T$. spiralis, and possibly $S$. stercoralis have been found. In Asia, A. lumbricoides, T. trichiura, E. vermicularis, $S$. japonicum, C. sinensis, Taenia spp., $T$. solium, Diphyllobothrium spp., D. latum, E. histolytica, G. duodenalis, Chilomastix mesnili, and E. granulosus have been found. In Oceania, A. lumbricoides has been found. In South America, ancylostomids, A. lumbricoides, T. trichiura, E. vermicularis, Trichostrongylus spp., Paragonimus spp., Diphyllobothrium spp., D. pacificum, $H y$ menolepis nana, Acanthocephala, Entamoeba spp., G. duodenalis, Cryptosporidium parvum, Cyclospora cayetanenis, Isospora belli, Sarcocystis hominis, and possibly $E$. coli have been found. In North America, ancylostomids, A. lumbricoides, T. trichiura, E. vermicularis, Trichostrongylus spp., Opisthorchiformes, Taenia spp., D. latum, D. pacificum, Hymenolepsis spp., Acan-

TABLE XI

Diphyllobothrium spp. finds, locality, country and date from ancient remains

\begin{tabular}{|c|c|c|c|}
\hline Archaeological site/mummy & Country & Date & References \\
\hline Coast ${ }^{a}$ & Peru & $10,000-4000 \mathrm{BP}$ & Reinhard \& Barnum 1991 \\
\hline Tiliviche, Iquique $^{a}$ & Chile & $4110-1950 \mathrm{BC}$ & Ferreira et al. 1984 \\
\hline Clairvaux, Jura & France & $5600 \mathrm{BP}$ & Dommelier-Espejo 2001 \\
\hline Arbon, Thurgau & Swiss & $3384-3370 \mathrm{BC}$ & Dommelier-Espejo 2001 \\
\hline Chalain, Jura ${ }^{b}$ & France & $32 \mathrm{nd}-25$ th century BC & $\begin{array}{l}\text { Bouchet et al. } 1995 \text {, } \\
\text { Dommelier et al. } 1998\end{array}$ \\
\hline Huaca Prieta & Peru & $3000 \mathrm{BC}$ & Callen \& Camaron 1960 \\
\hline Huarmey Valley ${ }^{a}$ & Peru & $2700-2850 \mathrm{BC}$ & Patrucco et al. 1983 \\
\hline Northern ${ }^{a}$ & Chile & $4000 \mathrm{BP}$ & Reinhard \& Aufderheide 1990 \\
\hline Saginow valey, Michigan $b, c$ & USA & $300 \mathrm{BC}-200 \mathrm{AD}$ & McClary 1972 \\
\hline Bremerhaven $^{b}$ & Germany & $100 \mathrm{BC}-500 \mathrm{AD}$ & Jansen Jr \& Over 1962 \\
\hline Karwinden Man ${ }^{b}$ & Prussia & $1500 \mathrm{BP}$ & Szidat 1944 \\
\hline Adak Island, Alaska ${ }^{a}$ & USA & $840 \mathrm{BP} \pm 40$ & Bouchet et al. 2001 \\
\hline Acre $^{b}$ & Israel & 13 th century $\mathrm{AD}$ & Mitchell \& Stern 2000 \\
\hline Oslo $b$ & Norway & 15 th century $\mathrm{AD}$ & Schia 1979 \\
\hline Lübeck & Germany & 15 th century AD & $\begin{array}{l}\text { Herrmann 1985, } \\
\text { Herrmann \& Schulz } 1986\end{array}$ \\
\hline Schleswig & Germany & Medieval Age & Herrmann 1985 \\
\hline Hameln & Germany & Medieval Age & Herrmann 1985 \\
\hline Freiburg & Germany & Medieval Age & Herrmann 1985 \\
\hline Regensburg & Germany & Medieval Age & Herrmann 1985 \\
\hline Buildir Island, Alaska & USA & $1400-1700 \mathrm{AD}$ & Bouchet et al. 1999 \\
\hline Montbeliard $b$ & France & 15 th -16 th century & New finding \\
\hline Namur $b$ & Belgium & 18 th century AD & New finding \\
\hline
\end{tabular}

a: Diphyllobothrium pacificum; $b$ : D. latum; $c$ : uncertain origin

TABLE XII

Other Cestode finds, locality, country and date from ancient remains

\begin{tabular}{|c|c|c|c|}
\hline Archaeological site/mummy & Country & Date & References \\
\hline Hogup Cave, Utah & USA & $5330-1250 \mathrm{BC}$ & Fry 1977 \\
\hline Santa Elina, Mato Grosso ${ }^{a}$ & Brazil & $4000-2000 \mathrm{BP}$ & New finding \\
\hline Danger Cave, Utah & USA & $20 \mathrm{AD}$ & Fry 1977 \\
\hline Elden Pueblo, Arizona ${ }^{b}$ & USA & $1070-1250 \mathrm{AD}$ & Reinhard et al. 1987 \\
\hline Antelope House, Arizona ${ }^{c}$ & USA & $1175-1250 \mathrm{AD}$ & Reinhard et al. 1987 \\
\hline Glen Canyon, Utah & USA & $1250-1300 \mathrm{AD}$ & Fry 1977 \\
\hline Newport, Rhode Island & USA & 18th century AD & Reinhard et al. 1986 \\
\hline
\end{tabular}

a: Hymenolepis nana; $b$ : Hymenolepis sp. + taeniid cestode; $c$ : Hymenolepis $\mathrm{sp}$. 
thocephala, G. duodenalis, E. granulosus, T. spiralis, and possibly $S$. stercoralis, Fasciola spp. and D. dendriticum have been found (Tables II-XV).

Ancylostomids, A. lumbricoides, T. trichiura and $E$. vermicularis have been found in the Americas much earlier than colonial times (Tables II-V). It can be inferred that humans have been infected by some parasites before the peopling of the New World, as already mentioned by Darling (1920) and Soper (1927) regarding ancylostomid in- fection. For the above-mentioned helminths, except probably for E. vermicularis, their main gate to the Americas was not a land route through Beringia (Araújo et al. 1988, Araújo \& Ferreira 1995, 1997, Reinhard 1992). To some helminths, such as ancylostomids and T.trichiura, soil temperature is crucial to evolve to an infective stage. Therefore, transmission was discontinued when infected prehistoric migrants moved through the cold northern territories, from Siberia to the Americas.

TABLE XIII

Acanthocephala finds, locality, country and date from ancient remains

\begin{tabular}{llll}
\hline Archaeological site/mummy & Country & Date & References \\
\hline Danger Cave, Utah & USA & 9500 BC, 8000 BC, 2000 BC and 20 AD & Fry \& Hall 1969 \\
Hogup Cave, Utah & USA & 8000 BC - 2000 BC & Fry \& Hall 1969, Fry 1970 \\
Dirty Shame Rockshelter, Oregon & USA & 4850 BC & Hall 1976 \\
Boqueirão Soberbo, Minas Gerais & Brazil & $4905 \pm 85-1325 \pm 60$ BP & New finding \\
Danger Cave, Utah & USA & $1869 \pm 60$ BC and 20 \pm 240 AD & Moore et al. 1969 \\
Gentio Cave, Minas Gerais $a$ & Brazil & $3490 \pm 120-430 \pm 70$ BP & New finding \\
Clyde's Cavern, Utah & USA & 2300 years and 400 - 1200 AD & Hall 1972 \\
Black Mesa, Arizona & USA & $900-1100$ AD & Gummerman et al. 1972 \\
Glen Canyon, Utah & USA & $900-1300$ AD & Fry 1977, Fry \& Hall 1969 \\
\hline
\end{tabular}

$a$ : human origin?

TABLE XIV

Protozoa finds, locality, country and date from ancient remains

\begin{tabular}{|c|c|c|c|}
\hline Archaeological site/mummy & Country & Date & References \\
\hline \multicolumn{4}{|l|}{ Entamoeba spp. } \\
\hline $\begin{array}{l}\text { Nahal-Mishmar }{ }^{a} \\
\text { Huari } \\
\text { Alto Ramírez } \\
\text { Atacamenha } \\
\text { Cabuza } \\
\text { Tihuanaco } \\
\text { El Plomo, Santiago }{ }^{b} \\
\text { Inca mummy }\end{array}$ & $\begin{array}{l}\text { Israel } \\
\text { Peru } \\
\text { Chile } \\
\text { Chile } \\
\text { Chile } \\
\text { Chile } \\
\text { Chile } \\
?\end{array}$ & $\begin{array}{l}160 \text { AD } \\
\text { Pre-Columbian } \\
\text { Pre-Columbian } \\
\text { Pre-Columbian } \\
\text { Pre-Columbian } \\
\text { Pre-Columbian } \\
\text { Pre-Columbian } \\
\text { ca. } 1500 \text { AD }\end{array}$ & $\begin{array}{l}\text { Witenberg } 1961 \\
\text { Fouant et al. } 1982 \\
\text { Fouant et al. } 1982 \\
\text { Fouant et al. } 1982 \\
\text { Fouant et al. } 1982 \\
\text { Fouant et al. } 1982 \\
\text { Pizzi \& Schenone } 1954 \\
\text { Pike 1967b }\end{array}$ \\
\hline \multicolumn{4}{|l|}{ Giardia duodenalis } \\
\hline $\begin{array}{l}\text { Andes } \\
\text { Big Bone Cave, Tennessee } \\
\text { Nahal-Mishmar } \\
\text { Antelope House, Arizona } \\
\text { Lübeck } \\
\text { Namur }\end{array}$ & $\begin{array}{l}? \\
\text { USA } \\
\text { Israel } \\
\text { USA } \\
\text { Germany } \\
\text { Belgium }\end{array}$ & $\begin{array}{l}3000-500 \mathrm{BP} \\
2177 \mathrm{BP} \pm 145 \\
160 \mathrm{AD} \\
1200 \mathrm{AD} \\
1600 \mathrm{AD} \\
18 \text { th century } \mathrm{AD}\end{array}$ & $\begin{array}{l}\text { Allison et al. } 1999 \\
\text { Faulkner et al. } 1989 \\
\text { Witenberg } 1961 \\
\text { Gonçalves et al. } 2002 \\
\text { Gonçalves et al. } 2002 \\
\text { Gonçalves et al. } 2002\end{array}$ \\
\hline \multicolumn{4}{|l|}{ Chilomastix mesnili } \\
\hline Nahal-Mishmar & Israel & $160 \mathrm{AD}$ & Witenberg 1961 \\
\hline \multicolumn{4}{|l|}{ Cryptosporidium parvum } \\
\hline Andes & $?$ & $3000-500 \mathrm{BP}$ & Allison et al. 1999 \\
\hline \multicolumn{4}{|l|}{ Cyclospora cayetanenis } \\
\hline Andes & $?$ & $3000-500 \mathrm{BP}$ & Allison et al. 1999 \\
\hline $\begin{array}{l}\text { Isospora belli } \\
\text { Andes }\end{array}$ & $?$ & $3000-500 \mathrm{BP}$ & Allison et al. 1999 \\
\hline \multicolumn{4}{|l|}{ Sarcocystis hominis } \\
\hline Andes & $?$ & $3000-500 \mathrm{BP}$ & Allison et al. 1999 \\
\hline
\end{tabular}

a: Entamoeba histolytica; $b$ : E. coli? 
TABLE XV

Non-intestinal human helminth finds, locality, country and date from ancient remains

\begin{tabular}{|c|c|c|c|}
\hline Archaeological site/mummy & Country & Date & References \\
\hline \multicolumn{4}{|l|}{ Echinococcus granulosus } \\
\hline $\begin{array}{l}\text { Mummies } \\
\text { Mt. Scopus, Jerusalem } \\
\text { Shultz site, Michigan }{ }^{a} \\
\text { Jerusalem } \\
\text { Cambridgeshire } \\
\text { South Dakota } \\
\text { ? } \\
\text { Winchester } \\
\text { Naestved } \\
\text { Kodiak Island, Alaska } \\
\text { Orkley }\end{array}$ & $\begin{array}{l}\text { Egypt } \\
\text { Middle East } \\
\text { USA } \\
\text { Middle East } \\
\text { England } \\
\text { USA } \\
\text { Swiss } \\
\text { England } \\
\text { Denmark } \\
\text { USA } \\
\text { Scotland }\end{array}$ & $\begin{array}{l}? \\
538 \mathrm{BC}-70 \mathrm{AD} \\
300 \mathrm{BC}-200 \mathrm{AD} \\
1 \text { st century AD } \\
1 \text { st - 2nd century AD } \\
600 \mathrm{AD} \\
\text { Medieval Age } \\
\text { Medieval Age } \\
1450 \mathrm{AD} \\
\text { before } 1740 \mathrm{AD} \\
?\end{array}$ & $\begin{array}{l}\text { Tapp } 1984 \\
\text { Arieli } 1998 \\
\text { McClary } 1972 \\
\text { Zias \& Mumcuoglu } 1991 \\
\text { Wells \& Dallas } 1976 \\
\text { Williams } 1985 \\
\text { Baud \& Kramar } 1991 \\
\text { Prince 1975 } \\
\text { Weiss \& Moller-Christensen } 1971 \\
\text { Ortner \& Putschar } 1981 \\
\text { Brothwell } 1978\end{array}$ \\
\hline \multicolumn{4}{|l|}{ Trichinella spiralis } \\
\hline $\begin{array}{l}\text { Nakht - ROM I mummy } \\
\text { Utqiagvik, Alaska } \\
\text { Toledo }\end{array}$ & $\begin{array}{l}\text { Egypt } \\
\text { USA } \\
\text { Spain }\end{array}$ & $\begin{array}{l}3200 \mathrm{BP} \\
440 \pm 70 \mathrm{BP} \\
19 \text { th century AD }\end{array}$ & $\begin{array}{l}\text { De Boni et al. } 1977 \\
\text { Zimmerman \& Aufderheide } 1984 \\
\text { Bellard \& Cortés } 1990\end{array}$ \\
\hline \multicolumn{4}{|l|}{ Dracunculus medinensis } \\
\hline $\begin{array}{l}\text { Tumb of Parannefer, Valley of the Nobles } \\
\text { Manchester mummy \# } 1770\end{array}$ & $\begin{array}{l}\text { Egypt } \\
\text { Egypt }\end{array}$ & $\begin{array}{l}1450 \text { BC } \\
\text { Greek or Roman period }\end{array}$ & $\begin{array}{l}\text { Horne \& Redford } 1995 \\
\text { Tapp } 1979\end{array}$ \\
\hline \multicolumn{4}{|l|}{ Filarial worm } \\
\hline Natsef Amun - Leeds mummy, Karnak & Egypt & $1100 \mathrm{BC}$ & Tapp \& Wildsmith 1992 \\
\hline
\end{tabular}

$a$ : uncertain origin

TABLE XVI

Paleoparasitological finds from human remains, in the New and Old World, pre and post-Columbian

\begin{tabular}{|c|c|c|c|c|}
\hline \multirow[b]{2}{*}{ Human paleoparasitological finds } & \multicolumn{2}{|c|}{ New World } & \multicolumn{2}{|c|}{ Old World } \\
\hline & $\begin{array}{c}\text { Pre-Columbian } \\
\text { parasite finds }\end{array}$ & $\begin{array}{l}\text { Post-Columbian } \\
\text { parasite finds }\end{array}$ & $\begin{array}{l}\text { Pre-Columbian } \\
\text { parasite finds }\end{array}$ & $\begin{array}{r}\text { Post-Columbian } \\
\text { parasite finds }\end{array}$ \\
\hline Ancylostomids & $\mathrm{Y}$ & $\mathrm{Y}$ & $\mathrm{Y}$ & $\mathrm{Y}$ \\
\hline Ascaris lumbricoides & Y & $\mathrm{Y}$ & $\mathrm{Y}$ & $\mathrm{Y}$ \\
\hline Trichuris trichiura & Y & $\mathrm{Y}$ & $\mathrm{Y}$ & Y \\
\hline Enterobius vermicularis & Y & NF & Y & $\mathrm{NF}$ \\
\hline Strongyloides stercoralis & $?$ & $\mathrm{NF}$ & $\mathrm{Y}$ & NF \\
\hline Trichostrongylus spp. & $\mathrm{Y}$ & Y & $\mathrm{NF}$ & $\mathrm{NF}$ \\
\hline Fasciola spp. & $?$ & $\mathrm{NF}$ & $\mathrm{Y}$ & $?$ \\
\hline Schistosoma spp. & NF & $\mathrm{NF}$ & $\mathrm{Y}$ & Y \\
\hline Dicrocoelium spp. & NF & $?$ & $\mathrm{Y}$ & NF \\
\hline Opisthorchiformes & $\mathrm{Y}$ & $\mathrm{NF}$ & $\mathrm{Y}$ & NF \\
\hline Paragonimus spp. & $\mathrm{Y}$ & NF & $\mathrm{NF}$ & NF \\
\hline Taenia spp. & NF & $\mathrm{Y}$ & $\mathrm{Y}$ & $\mathrm{Y}$ \\
\hline Diphyllobothrium spp. & $\mathrm{Y}$ & $\mathrm{Y}$ & $\mathrm{Y}$ & $\mathrm{Y}$ \\
\hline Hymenolepis spp. & $\mathrm{Y}$ & $\mathrm{NF}$ & $\mathrm{NF}$ & $\mathrm{NF}$ \\
\hline Acanthocephala & $\mathrm{Y}$ & $\mathrm{NF}$ & $\mathrm{NF}$ & $\mathrm{NF}$ \\
\hline Entamoeba spp. & $\mathrm{Y}$ & NF & $\mathrm{Y}$ & NF \\
\hline Giardia duodenalis & Y & $\mathrm{NF}$ & $\mathrm{Y}$ & Y \\
\hline Chilomastix mesnili & NF & $\mathrm{NF}$ & $\mathrm{Y}$ & NF \\
\hline Cryptosporidium parvum & $\mathrm{Y}$ & $\mathrm{NF}$ & $\mathrm{NF}$ & $\mathrm{NF}$ \\
\hline Cyclospora cayetanenis & $\mathrm{Y}$ & NF & NF & NF \\
\hline Isospora belli & $\mathrm{Y}$ & NF & NF & NF \\
\hline Sarcocystis hominis & $\mathrm{Y}$ & NF & NF & NF \\
\hline Echinoccus granulosus & $\mathrm{Y}$ & $\mathrm{Y}$ & $\mathrm{Y}$ & $?$ \\
\hline Trichinella spiralis & NF & $\mathrm{Y}$ & $\mathrm{Y}$ & $\mathrm{Y}$ \\
\hline Dracunculus medinensis & NF & $\mathrm{NF}$ & $\mathrm{Y}$ & $\mathrm{NF}$ \\
\hline Filarial worm & NF & NF & $\mathrm{Y}$ & NF \\
\hline
\end{tabular}

Y: yes; NF: not found 
The new findings presented here confirm ancylostomid and T. trichiura infection before Columbus's arrival. Dixon (2001), based on geological and archaeological data, hypothesizes that the first settlers used a sea-route along the southern coast of the Bering Land Bridge. Humans had vessels and were able to navigate near-shore waters prior to 14,000 BP(Dixon 2001). Whether by transoceanic route or coastal navigation, prehistoric settlers brought such soil-transmitted helminths to the New World, in a journey no longer than the life-span of these helminths.

As more sensitive techniques become available, as detection of parasite DNA by polymerase chain reaction and immunological antigen detection by monoclonal antibody assays, more parasitic infections will be detected. New paleoparasitological findings are been reported throughout the world, updating continuously the knowledge of parasite distribution in the past. A more complete and accurate parasitic infection understanding in antiquity will improve our knowledge about biological and social aspects of health and disease process during the evolution of human species. Coprolites, in Patrick Horne's words, one of the "least-attractive of man's relics", are helping scientist to disclose some still unclear aspects of parasitism and human dispersion in ancient times (Horne 1985).

We apologize for any data omission in the review. We would appreciate any aditional paleoparasitological finding sent by colleagues.

\section{REFERENCES}

Allison MJ, Bergman T, Gerszten E 1999. Further studies on fecal parasites in antiquity. Am Soc Clin Pathol 112: 605609.

Allison MJ, Pezzia A, Hasegawa I, Gerszten E 1974. A case of hookworm infestation in a pre-Columbian American. Am J Phys Anthropol 41: 103-106.

Andrews JRH 1976. Ascaris egg in coprolite material. New Zeland Med J 89: 274.

Araújo A, Ferreira LF 1995. Oxiuríase e migrações pré-históricas. Hist Cienc Saúde 2: 99-108.

Araújo A, Ferreira LF 1997. Homens e parasitos: a contribuição da paleoparasitologia para a questão da origem do homem na América. Rev USP 34: 58-70.

Araújo A, Ferreira LF 2000. Paleoparasitology and the antiquity of human host-parasite relationship. Mem Inst Oswaldo Cruz 95 (Suppl. I): 89-93.

Araújo A, Confalonieri U, Ferreira LF 1984. Encontro de ovos de Trichostrongylidae e Trichuris trichiura em corpo mumificado do período colonial brasileiro. Rev Centr Cienc Biol Saúde 1: 11-16.

Araújo A, Ferreira LF, Confalonieri U 1981. A contribution to the study of helminth findings in archaeological material in Brazil. Rev Bras Biol 41: 873-881.

Araújo A, Ferreira LF, Confalonieri U, Chame M 1988. Hookworms and the peopling of America. Cad Saúde Pública 2: 226- 233.

Araújo A, Ferreira LF, Confalonieri U, Nuñez L, Ribeiro Filho B 1985. The finding of Enterobius vermucularis eggs in pre-Columbian human coprolites. Mem Inst Oswaldo Cruz 80: 141-143.

Araújo A, Ferreira LF, Coura LC, Gonçalves MLC 2000. Parasitos, parasitismo e paleoparasitologia molecular. An Acad Nac Med 160: 20-27.
Arieli R 1998. Apud Hanson CL 1999. Annotated Bibliography. Paleopathol News 105: 13.

Aspöck H, Auer H, Picher O 1996. Trichuris trichiura eggs in the neolithic glacier mummy from the Alps. Parasitol Today 12: 255-256.

Aspöck H, Barth FE, Flamm H, Picher O 1974. Apud Aspöck H, Auer H, Picher O 1999. Parasites and parasitic diseases in prehistoric human populations in Central Europe. Helminthologia 36: 139-145.

Aspöck H, Flamm H, Picher O 1973. Darmparasiten in menschlichen exkrementen aus prähistorischen Salzbergwerken der Hallstatt-Kultur (800-350 v. Chr.). Zbl Bakt Hyg, I Abt Orig A 223: 549-558.

Baud CA, Kramar C 1991. Apud Reinhard KJ 1992. Parasitology as an interpretative tool in archaeology. Am Antiq 57: 231-245.

Bellard FG, Cortés A 1990. Trichinosis in the mummy of a young girl (Toledo, Spain). Papers on Paleopathology, 8th European Meeting, Cambrigde, p. 11.

Benninghoff WS 1947. Use of trisodium phosphate with herbarium material and microfossils in peat. Science 106: 325326.

Boersema JH, Jansen J 1975. Helminth infections in Medieval Utrecht. Trop Geo Med 27: 441.

Bouchet F 1993. Apport de la parasitologie sur les chantiers archéologiques - l'exemple de la ville de Paris. Mem Group Archeol Seine-et-Marne 1: 55-61.

Bouchet F 1995. Recovery of helminth eggs from archaeological excavations of the Grand Louvre (Paris, France). $J$ Parasitol 81: 785-787.

Bouchet F 1997. Intestinal capillariasis in neolithic inhabitants of Chalain (Jura, France). Lancet 349: 256.

Bouchet F, Baffier D, Girard M, Morel P, Paicheler JC, David F 1996. Paléoparasitologie en contexte pléistocène: premières observations à la Grande Grotte d'Arcy-sur-Cure (Yonne), France. C R Acad Sci Paris 319: 147-151.

Bouchet F, Bentrad S, Paicheler JC 1998. Enquête épidémiologique sur les helminthiases à la cour de Louis XIV. Mini-Synthese Med Sci 14: 463-466.

Bouchet F, Harter S, Paicheler JC, Araújo A, Ferreira LF 2002. First recovery of Schistosoma mansoni eggs from a latrine in Europe (15-16th centuries). J Parasitol 88: 404-405.

Bouchet F, Lefèvre C, West D, Corbett D 1999. First paleoparasitological analysis of a midden in the Aleutian Island (Alaska): results and limits. J Parasitol 85: 369-372.

Bouchet F, Paicheler JC 1995. Paléoparasitologie: présomption d'un cas de bilharziose au XV $\mathrm{V}^{\mathrm{e}}$ siècle à Montbéliard (Doubs, France). C R Acad Sci Paris 318: 811-814.

Bouchet F, Petrequin P, Paicheler JC, Dommelier S 1995. Première approche paléoparasitogique du site néolithique de Chalain (Jura, France). Bull Soc Path Ex 88: 265-268.

Bouchet F, West D, Lefèvre C, Corbett D 2001. Identification of parasitoses in a child burial from Adak Island (Central Aleutian Islands, Alaska). C R Acad Sci Paris 324: 123127.

Brothwell DR 1978. Apud Jones AKG 1982. Human parasite remains: prospects for a quantitative approach. In AR Hall, HK Kenward (eds), Environmental Archaeology in the Urban Context, Research Report no. 43, The Concil for British Archaeology, England, p. 66-70.

Cahill J, Reinhard K, Tarler D, Warnock P 1991. Scientists examine remains of ancient bathroom. Bibli Archaeol Rev 27: 64-69.

Callen EO, Camaron TWM 1960. A prehistoric diet revealed in coprolites. New Sci 8: 35-40.

Cheng TO 1984. Glimpses of the past from the recently unearthed ancient corpses in China. An Int Med 101: 714-715. 
Cockburn A, Barraco RA, Reyman TA, Peck WH 1975. Autopsy of an Egyptian mummy. Science 187: 1155-1160.

Coimbra Jr CEA, Mello DA 1981. Enteroparasitas e Capillaria sp. entre o grupo Suruí, parque indígena Aripuanã, Rondônia. Mem Inst Oswaldo Cruz 76: 299-302.

Confalonieri UE, Araújo A, Ferreira LF 1981. Trichuris trichiura infection in Colonial Brazil. Paleopathol News 35: 13-14.

Confalonieri UE, Ribeiro Filho B, Ferreira LF, Araújo A 1985. The experimental approach to paleoparasitology: desiccation of Trichuris trichiura eggs. Paleopathol News 51: 911.

Darling ST 1920. Observations on the geographical and ethnological distribution of hookworms. Parasitology 12: 217233.

De Boni U, Lenczner MM, Scott JW 1977. Autopsy of an Egyptian mummy (Nakht-ROM I). 6. Trichinella spiralis cysts. CMAJ 117: 461-476.

Deelder AM, Miller RL, De Jonge N, Krijger FW 1990. Detection of schistosome antigen in mummies. Lancet 335: 724725 .

Dittmar K, Teegen WR 2000. Fasciola hepatica eggs in a 4500 year old soil sample from the pelvic region of a human skeleton from Germany. Paleopathology Association 27th Annual Meeting, San Antonio, Texas, p. 6.

Dixon EJ 2001. Human colonization of the Americas: timing, technology and process. Quat Sci Rev 20: 277-299.

Dommelier-Espejo S 2001. Contribuition à L'étude Paléoparasitologique des Sites Néolithiques en Environnement Lacustre dans les Domaines Jurassien et Péri-alpin, Thesis, Université de Reims, Reims, 248 pp.

Dommelier S, Bentrad S, Paicheler JC, Petrequin P, Bouchet F 1998. Parasitoses liées à l' alimentation chez les populations néolithiques du lac de Chalain (Jura, France). Anthropozool 27: 41-49.

Dunn FL, Watkins R 1970. Apud Wilke PJ, Hall HJ 1975. Analysis of Ancient Feces: a Discussion and Annotated Bibliography, Archaeological Research Facility, Department of Anthropology, University of California, Berkeley, 47 $\mathrm{pp}$.

Dusseau EM, Porter RJ 1974. Apud Reinhard KJ 1990. Archaeoparasitology in North America. Am J Phys Anthropol 82: 145-163.

El-Najjar MY, Benitez J, Fry G, Lynn GE, Ortner DJ, Reyman TA, Small PA 1980. Autopsies on two native american mummies. Am J Phys Anthrop 53: 197-202.

Evans AC, Markus MB, Mason RJ, Steel R 1996. Late stoneage coprolite reveals evidence of prehistoric parasitism. SAMJ 86: 274-275.

Faulkner CT, Cowie SE, Martin PE, Martin SR, Mayes CS, Patton S 2000. Archeological evidence of parasitic infection from the 19th century company town of Fayette, Michigan. J Parasitol 86: 846-849.

Faulkner CT, Patton S 2001. Pre-Columbian hookworm evidence from Tennessee: a response to Fuller (1997). Med Anthropol 20: 92-96.

Faulkner CT, Patton S, Johnson SS 1989. Prehistoric parasitism in Tennessee: evidence from the analysis of desiccated fecal material collected from Big Bone Cave, Van Buren County, Tennessee. J Parasitol 75: 461-463.

Ferreira LF, Araújo A, Confalonieri U 1980. The finding of eggs and larvae of parasitic helminths in archaeological material from Unai, Minas Gerais, Brazil. Trans $R$ Soc Trop Med Hyg 74: 798-800.

Ferreira LF, Araújo A, Confalonieri U 1982. Untitled note. Paleopathol News 38: 5.

Ferreira LF, Araújo A, Confalonieri U 1983. The finding of helminth eggs in a brazilian mummy. Trans $R$ Soc Trop Med
Hyg 77: 65-67.

Ferreira LF, Araújo A, Confalonieri U, Chame M, Ribeiro Filho B 1987. The finding of hookworm eggs in human coprolites from $7230 \pm 80$ years BP, from Piauí, Brazil. An Acad Bras Cienc 59: 280-281.

Ferreira LF, Araújo A, Confalonieri U, Lima JMD 1989a. Trichuris eggs in human coprolites from archeological site of Furna do Estrago, Brejo da Madre de Deus, Pernambuco. Mem Inst Oswaldo Cruz 84: 581.

Ferreira LF, Araújo A, Confalonieri U, Nuñez L 1984. The finding of Diphyllobothrium pacificum in human coprolites (4100-1950 BC) from Northern Chile. Mem Inst Oswaldo Cruz 79: 175-180.

Ferreira LF, Araújo A, Confalonieri U, Nuñez L 1989b. Infecção por Enterobius vermicularis em populações agro-pastoris pré-colombianas de San Pedro de Atacama, Chile. Mem Inst Oswaldo Cruz 84 (Suppl. IV): 197-199.

Ferreira LF, Reinhard KJ, Araújo A, Coura LC 1997. Paleoparasitology of oxyuriasis. An Acad Nac Med 157: 20-24.

Fouant MM, Allison M, Gerszten E, Focacci G 1982. Parasitos intestinales entre los indigenas precolombinos. Rev Chungara 9: 285-299.

Fry G 1970 . Preliminary analysis of the Hogup Cave coprolites. In CM Aikens, Hogup Cave, University of Utah Antropological Papers, n. 93, University of Utah Press, Salt Lake City, p. 247-250.

Fry GF 1974. Apud Reinhard KJ 1990. Archaeoparasitology in North America. Am J Phys Anthropol 82: 145-163.

Fry GF 1977. Analysis of prehistoric coprolites from Utah. In JD Jennings, LS Sweeney, University of Utah Anthropological Papers, n. 97, University of Utah Press, Salt Lake City, 45 pp.

Fry GF 1985. Analysis of fecal material. In RI Gilbert Jr, J Mielke (eds), The Analysis of Prehistoric Diets, Academic Press, Orlando, p. 127-154.

Fry GF, Hall HJ 1969. Parasitological examination of prehistoric human coprolites from Utah. Proc Utah Acad Sci Art Letters 46: part 2, 102-105.

Fry GF, Hall HJ 1973. Apud Wilke PJ, Hall HJ 1975. Analysis of Ancient Feces: a Discussion and Annotated Bibliography. Archaeological Research Facility, Department of Anthropology, University of California, Berkeley, $47 \mathrm{pp}$.

Fry G, Hall HJ 1975. Human coprolites from Antelope House: preliminary analysis. Kiva 41: 87-96.

Fry GF, Moore JG 1969. Enterobius vermicularis: 10,000year-old human infection. Science 166: 1620.

Gardner SL, Clary K 1987. Helminth parasites of Anasazi period coprolites from Bighorn Sheep ruin [42SA1563], Canyonlands National Park, Utah. Manuscript.

Giuffra E, Kijas JMH, Amarger V, Carlborg Ö, Jeon JT, Andersson L 2000. The origin of the domestic pig: independent domestication and subsequent introgression. Genetics 154: 1785-1791.

Gonçalves MLC, Araújo A, Duarte R, Silva JP, Reinhard K, Bouchet F, Ferreira LF 2002. Detection of Giardia duodenalis antigen in coprolites using a commercially available enzyme immunoassay. Trans $R$ Soc Trop Med Hyg, in press.

Grzywinski L 1960. Analysis of feces from the Middle Age period. Zool Poloniae 10: 195-199.

Gummerman GJ, Westfall D, Weed CS 1972. Apud Reinhard KJ 1990. Archaeoparasitology in North America. Am J Phys Anthropol 82: 145-163.

Hall HJ 1972. Apud Wilke PJ, Hall HJ 1975. Analysis of Ancient Feces: a Discussion and Annotated Bibliography, Archaeological Research Facility, Department of Anthropol- 
ogy, University of California, Berkeley, $47 \mathrm{pp}$.

Hall HJ 1976. Untitled notes. Paleopathol News 13: 9.

Hall AR, Jones AKG, Kenward HK 1983. Cereal Bran and Human Faecal Remains from Archaeological Deposits Some Preliminary Observations. In B Proudfoot, Site, Environment and Economy, BAR International Series 173, Oxford, p. 85-104.

Hansen JPH 1986. Les momies du Groenland. La Recherche 183: 1490-1498.

Heizer RF, Napton LK 1969. Biological and cultural evidence from prehistoric human coprolites. Science 165: 563-568.

Helbaek H 1958. Grauballemandens sidste måltid. Kuml: 83116.

Herrmann B 1985. Parasitologisch-Epidemiologische Auswertungen Mittelalterlicher Kloaken. Z Archäol Mittelalters 13: 131-161.

Herrmann B, Schulz U 1986. Parasitologische Untersuchungen eines Spätmittelalterlich-Frühneuzeitlichen Kloakeninhaltes aus der Fronerei auf dem Schrangen in Lübeck. Lübecker Schri Archäol Kultur 12: 167-172.

Hevly RH, Kelly RE, Anderson GA, Olsen SJ 1979. Apud Reinhard KJ 1990. Archaeoparasitology in North America. Am J Phys Anthropol 82: 145-163.

Hill G 1990. Recent finds of parasitic evidence in coprolites. Paleopathol News 69: 9-10.

Horne PD 1985. A review of the evidence of human endoparasitism in the pre-Columbian New World through the study of coprolites. J Archaeol Sci 12: 299-310.

Horne P, Redford S 1995. Aspergillosis and dracunculiasis in mummies from the tomb of Parannefer. Paleopathol News 92: 10-12.

Horne PD, Tuck JA 1996. Archaeoparasitology at a 17th century colonial site in Newfoundland. J Parasitol 82: 512515.

Hugot JP, Reinhard KJ, Gardner SL, Morand S 1999. Human enterobiasis in evolution: origin, specificity and transmission. Parasite 6: 201-208.

Jansen J, Boersema JH 1972. Helminth eggs from the latrines of the Olofskapel Gatehouse, Amsterdam. Paleopathol News 2: ab7-ab8.

Jansen J, Boersema JH 1982. Helminth infection in medieval Amsterdam and Utrecht. Papers on Paleopathology, 4th European Members Meeting, Middelburg, Antwerpen, p. 6-7.

Jansen Jr J, Over HJ 1962. Het voorkomen van parasieten in terpmateriaal uit Noordwest Duitsland. Tijdschr Diergeneesk 87: 1377-1379.

Jansen Jr J, Over HJ 1966. Observations on helminth infections in a roman army-camp. Proc 1st Int Congr Parasitol, Roma, Italy, 1964, p. 791.

Jones AKG 1982. Recent finds of intestinal parasite ova at York, England. Papers on Paleopathology, 4th European Members Meeting, Middelburg, Antwerpen, p. 7.

Jones AKG, 1983. A coprolite from 6-8 pavement. In Council for British Archaeology, The Archaeology of York: The Past Environment of York, Environment and Living Conditions at Two Anglo-Scandinavian Sites, Council for British Archaeology, p. 225-229.

Jones AKG 1986. Parasitological investigations on Lindow Man. In IM Stead, JB Bourke, D Brothwell, Lindow Man The Body in the Bog, British Museum Publications, p. 136139.

Jones AKG, Hutchinson AR, Nicholson C 1988. The worms of Roman horses and other finds of intestinal parasite eggs from unpromising deposits. Antiquity 62: 275-276.

Jones AKG, Nicholson C 1988. Recent finds of Trichuris ans Ascaris ova from Britain. Paleopatol News 62: 5-6.
Liangbiao C, Tao H 1981. Scanning electron microscopic view of parasites worm ova in an ancient corpse. Acta Acad Sinicae 3: 64-65.

Lutz A 1919. O Schistosomum mansoni e a schistosomatose segundo observações feitas no Brasil. Mem Inst Oswaldo Cruz 11: 121-150.

Manter HW 1967. Some aspects of the geographical distribution of parasites. J Parasitol 53: 3-9.

McClary A 1972. Apud Wilke PJ, Hall HJ 1975. Analysis of Ancient Feces: a Discussion and Annotated Bibliography, Archaeological Research Facility, Department of Anthropology, University of California, Berkeley, $47 \mathrm{pp}$.

Miller RL, Armelagos GJ, Ikram S, De Jonge N, Krijger FW, Deelder AM 1992. Palaeoepidemiology of schistosoma infection in mummies. BMJ 304: 555-556.

Mitchell PD, Stern E 2000. Parasitic intestinal helminth ova from the latrines of the 13th century crusader hospital of St John in Acre, Israel. Paleopathology Association 13th Biennial European Members Meeting, Chieti, p. 21-22.

Moore DP 1981. Life seen from a medieval latrine. Nature 294: 644.

Moore JG, Fry GF, Englert Jr E 1969. Thorny-headed worm infection in North American prehistoric man. Science 163: 1324-1325.

Moore JG, Grundmann AW, Hall HJ, Fry GF 1974. Human fluke infection in Glen Canyon at AD 1250. Am J Phys Antropol 41: 115-118.

Nansen P, Jørgensen RJ 1977. Fund af parasitæg i arkæologisk materiale fra det vikingetidige Ribe. Nord Vet-Med 29: 263266.

Ortner DJ, Putschar WGJ 1981. Reinhard KJ 1990. Archaeoparasitology in North America. Am J Phys Anthropol 82: 145-163.

Patrucco R, Tello R, Bonavia D 1983. Parasitological studies of coprolites of pre-hispanic peruvian populations. Curr Anthropol 24: 393-394.

Pike AW 1967a. The recovery of parasite eggs from ancient cesspit and latrine deposits: an approach to the study of early parasite infections. In D Brothwell, AT Sandison (eds), Diseases in Antiquity, CC Thomas, Springfield, p. 184-188.

Pike AW 1967b. Apud Moore JG, Fry GF, Englert Jr E 1969. Science 163: 1324-1325.

Pike AW 1968. Recovery of helminth eggs from archaeological excavations, and their possible usefulness in providing evidence for the purpose of an occupation. Nature 219: 303304.

Pike AW 1975. Parasite eggs. In C Platt, R Coleman-Smith, Excavations in Medieval Southampton, Leicester University Press, Leicester, p. 347-348.

Pike AW, Biddle M 1966. Parasite eggs in Medieval Winchester. Antiquity 40: 293-296.

Pizzi T, Schenone H 1954. Hallazgo de huevos de Trichuris trichiura en contenido intestinal de un cuerpo arqueológico incaico. Bol Chil Parasitol 9: 73-75.

Prince JL 1975. Apud Wells C, Dallas C 1976. Romano-british pathology. Antiquity 50: 53-55.

Rathbun TA, Sexton J, Michie J 1980. Apud Reinhard KJ 1990. Archaeoparasitology in North America. Am J Phys Anthropol 82: 145-163.

Reinhard KJ 1988a. Cultural ecology of prehistoric parasitism on the Colorado Plateau as evidenced by coprology. Am J Phys Anthropol 77: 355-366.

Reinhard KJ 1988b. Diet, Parasitism and Anemia in the Prehistoric Southwest, Thesis, Department of Anthropology, Texas A \& M University, Texas, $120 \mathrm{pp}$.

Reinhard KJ 1990. Archaeoparasitology in North America. Am J Phys Anthropol 82:145-163. 
Reinhard KJ 1992. Parasitology as an interpretative tool in archaeology. Am Antiq 57: 231-245.

Reinhard KJ, Ambler JR, McGuffie M 1985. Diet and parasitism at Dust Devil Cave. Am Antiq 50: 819-824.

Reinhard KJ, Aufderheide AC 1990. Diphyllobothriasis in preColumbian Chile and Peru: adaptative radiations of a helminth species to native american populations. Papers on Paleopathology, 8th European Members Meeting, Cambrigde, p.18.

Reinhard KJ, Barnum SV 1991. Apud Reinhard KJ 1992. Parasitology as an interpretative tool in archaeology. Am Antiq 57: 231-245.

Reinhard KJ, Bryant Jr VM 1992. Coprolites analysis: a biological perspective on archaeology. In MB Schiffer, $A d$ vances in Archaeological Method and Theory, Vol. 4, Academic Press, New York, p. 245-288.

Reinhard KJ, Clary KH 1986. Apud Steinbock RT 1987. Annotated Bibliography. Paleopathol News 59: 19.

Reinhard KJ, Brooks RH, Brooks S, Largent Jr FB 1989. Apud Reinhard KJ 1990. Archaeoparasitology in North America. Am J Phys Anthropol 82: 145-163.

Reinhard KJ, Hevly RH, Anderson GA 1987. Helminth remains from prehistoric indian coprolites on the Colorado Plateau. J Parasitol 73: 630-639.

Reinhard KJ, Mrozowski SA, Orloski KA 1986. Privies, pollen, parasites and seeds: a biological nexus in historic archaeology. Masca J 4: 31-36.

Rey L 2001. Parasitologia, 3rd ed., Guanabara Koogan, Rio de Janeiro, $856 \mathrm{pp}$.

Reyman TA, Zimmerman MR, Lewin PK 1977. Autopsy of an Egyptian mummy (Nakht-ROM I). 5. Histopathologic investigation. CMAJ 117: 461-476.

Roberts LS, Janovy Jr J 2000. Gerald D Schmidt \& Larry S Roberts' Foundations of Parasitology, 6th ed., McGrawHill, Boston, 670 pp.

Roever-Bonnet H, Rijpstra C, van Renesse MA, Peen CH 1979. Helminth eggs and gregarines from coprolites from the excavations at Swifterbant. Helinium 19: 7-12.

Rousset JJ, Heron C, Metrot P 1996. Human helminthiasis at the gauls. Hist Sci Med 30: 41-46.

Ruffer MA 1910. Note on the presence of Bilharzia haematobia in Egyptian mummies of the twentieth dynasty. $\mathrm{Br} \mathrm{Med} \mathrm{J}$ 1: 16.

Samuels R 1965. Parasitological study of long-dried fecal samples. Paleopathol News 2: ab4.

Schia E 1979. Apud Jones AKG 1982. Human parasite remains: prospects for a quantitative approach. In AR Hall, HK Kenward (eds), Environmental Archaeology in the Urban Context, Research Report no. 43, The Concil for British Archaeology, p. 66-70.

Šebela L, Vojtková L, Vojtek J 1990. Apud Aspöck H, Auer H, Picher O 1999. Parasites and parasitic diseases in prehistoric human populations in Central Europe. Helminthologia 36: 139-145.

Soper FL 1927. The report of nearly pure Ancylostoma duodenalis infection in native South American indians and a discussion of its ethnological significance. Am J Hyg 7: 174-184.

Specht KW 1963. Eine interessante Erdprobe aus einer Abortgrube im Römerkastell Künzing. Saalburg-Jahrbuch 21: $90-94$

Stiger MA 1977. Apud Reinhard KJ 1990. Archaeoparasitology in North America. Am J Phys Anthropol 82: 145-163.

Szidat L 1944. Über die Erhaltungsfähigkeit von Helmintheneiern in Vor- und Frühgeschichtlichen Moorleichen. $Z$ Parasitenkd 13: 265-274.

Tapp E 1984. Apud Sandinson AT, Tapp E 1998. Disease in ancient Egypt. In A Cockburn, E Cockburn, TA Reyman (eds), Mummies, Disease \& Ancient Cultures, 2nd ed., Cambridge University, Cambridge.

Tapp E, Wildsmith K 1992. Apud Sandinson AT, Tapp E 1998. Disease in ancient Egypt. In A Cockburn, E Cockburn, TA Reyman (eds), Mummies, Disease \& Ancient Cultures, 2nd ed., Cambridge University, Cambridge, p. 38-58.

Taylor EL 1955. Parasitic helminths in medieval remains. Vet Rec 67: 218-228.

Van Cleave HJ, Ross JA 1947. A method for reclaiming dried zoological specimens. Science 105: 318.

Wei O 1973. Internal organs of a 2100-year-old female corpse. Lancet 7839: 1198.

Weiss DL, Moller-Christensen V 1971. Apud Wells C, Dallas C 1976. Romano-British pathology. Antiquity 50: 53-55.

Wells C, Dallas C 1976. Romano-british pathology. Antiquity 50: 53-55.

Wilke PJ, Hall HJ 1975. Analysis of ancient feces: a discussion and annotated bibliography. Archaeological Research Facility, Department of Anthropology, University of California, Berkeley, $47 \mathrm{pp}$.

Williams JA 1985. Evidence of hydatic cyst disease in a Plains Woodland Burial. Plains Anthropol 30: 25-28.

Wilson A, Rackham DJ 1976. Parasite eggs. In Council for British Archaeology, The Archaeology of York: The Past Environment of York, the Environment Evidence from the Church Street Sewer System, Council for British Archaeology, p. 32-33.

Witenberg G, 1961. Human parasites in archaeological findings. Bull Israel Expl Soc 25: 86.

Yang W, Song G, Teng R 1984. Parasitologische Untersuchung einer alten Leiche aus der Chu-Dynastie der Streitenden Reiche aus dem Mazhuan-Grab Nr. 1, Kreis Jiangling, Provinz Hubei. Acta Acad Med Wuhan 4: 23-27.

Zias J, Mumcuoglu KY 1991. Case reports on paleopathology: calcified hydatid cysts. Paleopathol News 73: 7-8.

Zimmerman MR 1980. Apud Sandinson AT, Tapp E 1998. Disease in ancient Egypt. In A Cockburn, E Cockburn, TA Reyman (eds), Mummies, Disease \& Ancient Cultures, 2nd ed., Cambridge University, Cambridge, p. 138-153.

Zimmerman MR, Aufderheide C 1984. The frozen family of Utqiagvik: the autopsy findings. Artic Anthropol 21: 53-64.

Zimmerman MR, Morilla RE 1983. Enterobiasis in preColumbian America. Paleopathol News 42: 8. 